\title{
The effect of OHS costs on accident severity rate in the construction industry
}

İnşaat sektöründe İSG maliyetlerinin kaza şiddet oranına etkisi

\author{
Zeynep Feride Olcay ${ }^{1}$ \\ Gülümser Ünkaya²
}

Günay Deniz Dursun 3

\author{
${ }^{1}$ Assist. Prof., İstanbul Aydın University, \\ İstanbul, Turkey, \\ zeynepolcay@aydin.edu.tr
}

ORCID: 0000-0001-5720-7350

2 Prof. Dr., İstanbul Aydın University, İstanbul, Turkey, gulumserunkaya@aydin.edu.tr

ORCID: 0000-0003-2453-2223

\author{
${ }^{3}$ Assoc. Prof. Dr., Beykent University, \\ İstanbul, Turkey, \\ gunaydursun@gmail.com
}

ORCID: 0000-0002-1079-2879

\section{Corresponding Author: \\ Zeynep Feride Olcay,}

İstanbul Aydın University, Istanbul, Turkey, zeynepolcay@aydin.edu.tr

Submitted: $1 / 07 / 2021$

Revised: $2 / 08 / 2021$

Accepted: 10/08/2021

Online Published: 25/09/2021

Citation: Olcay, Z.F., \& Ünkaya, G., \& Dursun, G.D., The effect of OHS costs on accident severity rate in the construction industry, bmij (2021) 9 (3): 1076-1087, doi: https://doi.org/10.15295/bmij.v9i3.1877

\begin{abstract}
Due to its dynamic nature, rapid technology change, uneducated employees, harsh working conditions, many work accidents, and heavy consequences of accidents, occupational health and safety (OHS) practices are essential in the construction industry. However, occupational Health and Safety measures in the construction industry come with additional costs. Therefore, employers who have to bear a cost to take OHS measures may consider OHS costs unnecessary without considering the costs they will bear after work accidents and occupational diseases. This research aims to estimate the optimal costs of OHS budgets to reduce the number of accidents with lost time injury and whether the carried costs for occupational health and safety in the construction industry impact the lost time injuries. Therefore, OHS costs in the construction industry are grouped into eight categories: fire, work equipment, electricity, health, personal protective equipment, general equipment, training and occupational health and safety service costs. This research is based on the standard unit costs set for the 8 OHS criteria required by the OHS laws, accident severity rates and actual unit costs that the projects have carried for five years for the construction of 15 buildings with $220.000 \mathrm{~m} 2-500.000 \mathrm{~m} 2$ indoor space which is located in Istanbul Turkey, started in 2013 and completed in 2017. Since the research was conducted before January 1, 2020, there is no requirement for an ethics committee permission document. According to the research results, as the costs of occupational health and safety services, fire and training increased, accident severity rates has decreased. However, the impact of other variables on accident severity rates was not statistically significant. Thus, construction enterprises that want to decrease the accident severity rates in their projects need to emphasise occupational health and safety services, fire, and training criteria.
\end{abstract}

Keywords: Occupational Health and Safety, Costs, Accident Severity Rate, Construction Industry

Jel Codes: D23, D24

Öz

Dinamik yapısı, teknolojinin hızlı değișimi, eğitimsiz çalıșanlar, çalışma şartlarının zorluğu, is kazası sayısının fazla olması ve kazaların ağır sonuçlarından dolayı inşaat sektöründe iş sağlığı ve güvenliği (ISG) uygulamaları çok fazla önem taşımaktadır. İnşaat sektöründe İş Sağlığı ve Güvenliği önlemleri beraberinde ek maliyetler getirmektedir. ISG tedbirlerini almak için bir maliyete katlanmak zorunda kalan işverenler, iş kazası ve meslek hastalıkları sonrasında katlanacakları maliyetleri düšünmeksizin İSG maliyetlerini gereksiz görebilmektedirler. Bu çalışmanın amac1, inşaat sektöründe İSG konusunda katlanılan maliyetlerin, kayıp günlü is kazaları üzerinde bir etkisinin olup olmadığı ve kayıp iş günlü kaza sayısını azaltmak için, İSG ile ilgili bütçelerin optimal maliyetlerini hesaplamaktır.Bunun için, inșaat sektöründe İSG maliyetleri; yangın, iș ekipmanları, elektrik, sağlık, kişisel koruyucu donanımlar, genel ekipmanlar, eğitim ile iş sağlığı ve güvenliği hizmet maliyetleri olarak sekiz başlıkta toplanmıștır. Bu araștırma, Türkiye' nin İstanbul ilinde bulunan 2013'te başlayan ve 2017 'de tamamlanan, $220.000 \mathrm{~m} 2-500.000 \mathrm{~m} 2$ kapalı alanı olan 15 bina inşaatı projesinde İSG mevzuatının zorunlu kıldığı 8 İSG kriteri için belirlenen standart birim maliyetler ile 5 yıl boyunca projelerin katlanmış olduğu fiili birim maliyetler ve kaza ağırlık oranlarından yararlanılmıştır. Araştırma 1 Ocak 2020'den önce yapıldığından etik kurul izin belgesi gerekliliği bulunmamaktadır. Çalışmanın sonuçlarına göre; İş sağlığı ve güvenliği hizmetleri, yangın ve eğitim maliyetleri arttıkça, kaza ağırlık oranının azaldığı görülmüştür. Diğer değişkenlerin kaza ağırlık oranı üzerindeki etkileri, istatistiksel olarak anlamlı çıkmamıştır. Bu sonuçlardan hareketle; projelerinde kaza ağırlık oranını azaltmak isteyen inşaat firmalarının; iş sağlığı ve güvenliği hizmetleri, yangın ve eğitim kriterlerine daha fazla önem vermeleri gerekmektedir.

Anahtar Kelimeler: İş Sağlığı ve Güvenliği, Maliyetler, Kaza Şiddet Oranı, İnşaat Sektörü

Jel Kodlari: D23, D24 


\section{Introduction}

Occupational accident rates in the construction sector, which has an intense workforce globally, are pretty high compared to other sectors (Loosemore \& Andonakis, 2007; Montero, Araque \& Rey, 2009). In Turkey, the construction sector ranks first among the riskiest sectors due to many occupational accidents, injuries and fatal outcomes. Therefore, the issue of occupational health and safety has recently gained more and more importance, especially in the construction sector. As a result, the concept of occupational safety has emerged to eliminate hazards and risks and create a safer working environment. Over time, occupational health and safety are considered a more autonomous and technical discipline (Gerek, 2006: 3).

The construction industry, providing employment opportunities and creating a boom in the economy, has maintained the leading sector globally. However, aside from affecting the economy positively, construction, with its diversity in work areas and entails risk arising from its complex nature, is the industry in which more work accidents occur compared to other industries (Briesemeister, 2018). Research has shown that construction workers are twice as likely to suffer injuries and three times more likely to die due to work accidents than other industries (Sousa, Almedia \& Diaz, 2014). Therefore, safety management is one of the most prominent elements of construction management (Gürcanl1, Bilir \& Sevim, 2015: 12).

In addition to the negative social consequences of work accidents, the economic aspects of this situation should also be considered for both the employer and the state. The budget employers will allocate to take measures against preventing work accidents is much less than the cost they have to carry after a work accident (Bütüner \& Uzun, 2010). There are expected and unexpected costs of accidental injuries, accidents that result in temporary or permanent incapacity to work, or death. Accident costs were addressed by Heinrich (1931) almost 90 years ago. He classified the accident costs as direct and indirect costs, concluding that indirect costs are four times more than direct ones (Heinrich, 1931). Direct costs are merely the tip of the accident costs iceberg compared to indirect costs (Bird, 1974). Significance in safety and health issues to establish appropriate working conditions and business connections and increase health and safety performance in constructions also has substantial economic importance in eliminating direct and indirect costs (Everett \& Frank, 1996).

As the number of workplaces and workers increases in the construction industry, many workers are injured and lose their lives every year. According to the Social Security Institution (SGK) statistics, 359,653 work accidents occurred in 2017 in Turkey, of which 62.802 (\% 17.5) occurred in the construction industry. Furthermore, $587(36 \%)$ of 1,633 work accident-related deaths in all industries are work accidents in the construction industry (SGK, 2018).

The number of work accidents in the construction industry is so high, and the results in heavy losses suggest that more emphasis should be placed on occupational health and safety. Minimizing work accidents that reach an alarming number nowadays and might result in irreversible consequences will only be possible by ensuring safe working conditions and mutually mindful and conscious approaches of employers and employees of all levels (Ercan, 2010:51). 88\% of work accidents occur due to dangerous actions, $10 \%$ to dangerous conditions, and $2 \%$ to unavoidable events (such as disasters). This means that $98 \%$ of work accidents are preventable (Ceylan, 2012).

Factors that can lead to accidents in the working environment in the construction can be classified as physical, chemical, biological, ergonomic, psychosocial, and personal factors. Only if the employers do not consider the cost of occupational health and safety in construction they will carry as a burden, and achieve an awareness that accident preventive costs will be less than the costs they will have to carry after a work accident, the establishment of the system will become easier.

Cohen (1977) emphasized the importance of establishing proper communication and training between employees and management on occupational safety issues as factors contributing to low accident rates, while Smith (1979) mentioned that the costs incurred in OHS are an indicator of the management's commitment to occupational safety and that this approach can reduce the number of accidents. Researches conducted on cost-benefit analyzes of OHS-related expenditures show that the costs arising from occupational accidents are much higher than occupational safety expenditures (Koç \& Akbiyık, 2011). Employers, who are aware that it is possible to reduce employer costs and increase employer profits by preventing injuries as a result of work accidents, will be more moderate in taking the necessary precautions by approaching the issue of occupational safety meticulously (Miller, 1997). 


\section{Purpose of research}

The purpose of this research is to determine whether if complying with the eight criteria of occupational health and safety cost determined according to OHS law has an impact on evaluating and reducing accident severity rate for the construction of 15 buildings with accessible data, out of which approximately 75 projects; started in 2013 and completed in 2017 in Istanbul, sizing $220.000-500.000$ $\mathrm{m}^{2}$. Determining the optimal OHS costs will minimize the number of accidents in the construction industry.

\section{Research data}

A total of 9 variables, one dependent (explained) and eight independents (explanatory), were used in the study.

Dependent variable; Accident severity rate (ASR)

$$
\text { Accident Severity Rate }=\frac{\text { Total of Lost Workday }}{\text { Total of Workday }- \text { Total of Days }- \text { off }} * 1000
$$

ASR is the value obtained by multiplying the total of lost time accidents occurred in a given period by the coefficient of 1000 in the ratio of the actual total workday in the said period. Thus, each loss in the 1000-day working period represents the number of working days (Keskin, 2016).

According to the lost day work accidents in the projects, the accident severity rates calculated according to the formula given above for each project every year are presented in Table 1. Public holidays and weekends are subtracted from 365 working days, and a total of 300 working days for a year is taken as a basis.

Table 1: Accident Severity Rates

\begin{tabular}{|c|c|c|c|c|c|}
\hline PROJECT / YEAR & 2013 & 2014 & 2015 & 2016 & 2017 \\
\hline PROJECT 1 & 0.079 & 0.117 & 0.091 & 0.084 & 0.085 \\
\hline PROJECT 2 & 0.069 & 0.066 & 0.079 & 0.079 & 0.068 \\
\hline PROJECT 3 & 0.236 & 0.265 & 0.177 & 0.277 & 0.538 \\
\hline PROJECT 4 & 0.118 & 0.086 & 0.141 & 0.145 & 0.184 \\
\hline PROJECT 5 & 0.285 & 0.396 & 0.422 & 3.68 & 0.423 \\
\hline PROJECT 6 & 0.142 & 0.139 & 0.136 & 0.172 & 0.195 \\
\hline PROJECT 7 & 0.125 & 0.117 & 0.995 & 0.118 & 0.133 \\
\hline PROJECT 8 & 0.116 & 0.108 & 0.121 & 0.134 & 0.140 \\
\hline PROJECT 9 & 0.654 & 0.672 & 3.994 & 0.455 & 0.582 \\
\hline PROJECT 10 & 0.427 & 0.326 & 0.371 & 0.452 & 0.394 \\
\hline PROJECT 11 & 0.083 & 0.076 & 0.092 & 0.101 & 0.083 \\
\hline PROJECT 12 & 0.227 & 0.286 & 0.195 & 0.182 & 0.213 \\
\hline PROJECT 13 & 0.102 & 0.097 & 0.115 & 0.128 & 0.129 \\
\hline PROJECT 14 & 0.367 & 3.89 & 4.762 & 0.451 & 0.674 \\
\hline PROJECT 15 & 0.164 & 0.189 & 0.221 & 0.197 & 0.341 \\
\hline
\end{tabular}


As seen in Table 1, comparing the accident severity rate of the projects, the lowest value was in Project 2 in 2014, and the highest value of 4.762 was in Project 14 in 2015. The more the number of lost times resulting from a work accident, the higher the accident severity rate is. The underlying reason for the calculated highest value of accident severity rate for the Project 14 is that two fatal work accidents occurred in 2015. In case of a fatal work accident, 7500 days are added to each person's total number of lost times concerning the accident severity rate formula.

Independent Variables: 8 criteria determined according to the Occupational Health and Safety law are this study's independent variable. These criteria are as follows:

Fire-related criteria (FRE),

Work equipment related criteria (WRK),

Electricity related criteria (ELC),

Health-related criteria (HEA),

Personal protective equipment related criteria (PERP),

General equipment related criteria (GNR),

Training related criteria (TRN) and

Occupational safety services related criteria (OHSC).

Data was realized using the domestic producer price index published by TURKSTAT for the manufacturing industry (PPI, 2003=100) and used in the analysis. The formula used in realization is as below:

$$
\text { Real Value of Series }=\frac{\text { Nominal Value of Series }}{\text { PPI }} * 100
$$

Source: $\underline{\text { www.khanacademy.org }}$

Descriptive statistics for the data set are given in Table 2.

Standard unit costs for independent variables in Table 2 are calculated as $\mathrm{m}^{2}$ and per person every year. Price quotes were obtained from 3 different occupational health and safety companies for each criterion. Finally, arithmetic averages of the obtained price quotes were calculated.

Actual data for the independent variables required by the OHS law obtained from the construction companies for each project and $\mathrm{m}^{2}$ and per person unit costs were calculated. Therefore, the data mentioned above is presented as ' $\mathbf{y}=\mathbf{a}+\mathbf{b x}$ ' to calculate the total cost function.

This research expects that complying with the occupational health and safety criteria will decrease the accident severity rates. Hypothesis formed according to this are as follows:

$\mathrm{H}_{0}$ : Actual costs of occupational health and safety of projects do not impact accident severity rates.

$\mathrm{H}_{1}$ : Actual costs of occupational health and safety of projects impact accident severity rates. 
Table 2: OHS Standard Unit Costs According to OHS Law Requirements

\begin{tabular}{|c|c|c|c|c|c|c|}
\hline & ڤ̊ํํ & ت্ّ亍 & ํㅗㄱ & 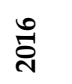 & 고ํ & UNIT \\
\hline FIRE & 6.81 & 7.23 & 7.79 & 8.42 & 0.48 & TL/M2 \\
\hline Fire Extinguishers & \multirow{2}{*}{0.13} & \multirow{2}{*}{0.13} & \multirow{2}{*}{0.14} & \multirow{2}{*}{0.16} & \multirow{2}{*}{0.18} & \multirow{2}{*}{ TL/M2 } \\
\hline (CAMP-OFFICE) & & & & & & \\
\hline Fire Detection and Alarm Systems & \multirow{2}{*}{3.64} & \multirow{2}{*}{3.87} & \multirow{2}{*}{4.09} & \multirow{2}{*}{4.5} & \multirow{2}{*}{0} & \multirow{2}{*}{ TL/M2 } \\
\hline (CAMP-OFFICE) & & & & & & \\
\hline Fire Equipment's Periodical Check & \multirow{2}{*}{0.21} & \multirow{2}{*}{0.22} & \multirow{2}{*}{0.24} & \multirow{2}{*}{0.26} & \multirow{2}{*}{0.3} & \multirow{2}{*}{ TL/M2 } \\
\hline (CAMP-OFFICE) & & & & & & \\
\hline Emergency Lighting and Guidance & \multirow{2}{*}{2.83} & \multirow{2}{*}{3.01} & \multirow{2}{*}{3.18} & \multirow{2}{*}{3.50} & \multirow{2}{*}{0} & \multirow{2}{*}{ TL/M2 } \\
\hline (CAMP-OFFICE) & & & & & & \\
\hline HEAVY AND LIFTING EQUIPMENT & 0 & 0.14 & 0.14 & 0.02 & 0 & TL/M2 \\
\hline Periodical checks on lifts, tower cranes and lifting equipment & 0 & 0.05 & 0.05 & 0.02 & 0 & TL/M2 \\
\hline Tower crane alarm system & 0 & 0.07 & 0.07 & 0 & 0 & TL/M2 \\
\hline Heavy Equipment (Excavator, etc.) & 0 & 0.02 & 0.02 & 0.00 & 0 & TL/M2 \\
\hline ELECTRICITY & 0 & 0.02 & 0.02 & 0.02 & 0.03 & TL/M2 \\
\hline Periodical Check on Electric and Grounding Systems & 0 & 0.02 & 0.02 & 0.02 & 0.03 & TL/M2 \\
\hline HEALTH & 29 & 31 & 33 & 36 & 42 & TL / PERSON \\
\hline Pre-recruitment and periodic health examinations & 29 & 31 & 33 & 36 & 42 & TL / PERSON \\
\hline PERSONAL PROTECTIVE EQUIPMENT & 129 & 137 & 145 & 159 & 184 & TL / PERSON \\
\hline GENERAL EQUIPMENT EXPENSES & 0 & 2.04 & 2.27 & 0 & 0 & TL/M2 \\
\hline Elevator Shaft Safety Nets & 0 & 0.59 & 0.62 & 0 & 0 & TL/M2 \\
\hline External Safety Nets & 0 & 0.86 & 0.93 & 0 & 0 & TL/M2 \\
\hline External railing and barrier systems -Safety fencing nets & 0 & 0.59 & 0.72 & 0 & 0 & TL/M2 \\
\hline TRAINING & 67 & 71 & 76 & 84 & 96 & TL / PERSON \\
\hline First Aid Training & 17 & 18 & 19 & 21 & 24 & TL / PERSON \\
\hline Technical Training & 49 & 52 & 55 & 61 & 70 & TL / PERSON \\
\hline Fire Safety Training & 1 & 1 & 2 & 2 & 2 & TL / PERSON \\
\hline OCCUPATIONAL HEALTH AND SAFETY SERVICE & 696 & 718 & 738 & 776 & 840 & TL/PERSON \\
\hline Occupational Safety Specialist & 388 & 397 & 408 & 436 & 480 & TL / PERSON \\
\hline Occupational Health Physician & 214 & 219 & 226 & 230 & 240 & TL / PERSON \\
\hline Occupational Health Nurse & 94 & 102 & 104 & 110 & 120 & TL / PERSON \\
\hline
\end{tabular}

\section{Research method and findings}

Analysis based solely on data collected at a single point in time, rather than a period, is called crosssectional analysis (Gujarati, 2004: 25). However, analysis based on a single section (i.e. country or company data) which includes more than one period of time, is called time series analysis (Gujarati, 2004: 27).

An increase in the number of observations eliminates the multicollinearity issue (Hsiao, 2006: 7). This research samples multiple projects and five years of data. Therefore, since panel data analysis will be used under the circumstances of availability in multiple sections and periods, applicable data for this study is panel data (Gujarati, 2004:28).

As for forming models in this study to research whether costs related to Occupational Health and Safety impact accident severity rates, the first model includes all explanatory variables. 
Model 1: $A S R_{i t}=\lambda_{0}+\lambda_{1} F R E_{i t}+\lambda_{2} W R K_{i t}+\lambda_{3} E L C_{i t}+\lambda_{4} H E A_{i t}+\lambda_{5} P E R P_{i t}+\lambda_{6} G N R_{i t}+\lambda_{7} T R N_{i t}+$ $\lambda_{8} O H S C_{i t}+e_{i t}$

The model including all independent variables; however, redundancy makes it challenging to determine the effect of independent variables on dependent variables (some effects may be lost) (TorresReyna, 2007: 25). Since using more than one variable in a single model will reduce the degree of freedom of the model (Kök \& Şimşek, 2005: 7), the correlation matrix was examined to determine the variables most associated with the accident severity rate.

The correlation matrix was created using the Eviews 9 program in the study, and the variables were listed starting from the most correlated variable by absolute value in MS Office 2013 Excel.

According to the correlation matrix results, occupational health and safety services, personal protective equipment, training, and fire were the most correlated variables with accident severity rates. Therefore, it is assumed that the degrees of freedom will be low in the regression model to be created with the first four variables, which are found to have the highest degree of relationship on the accident severity rate. For this reason, a model for the effects of occupational health and safety services and personal protective equipment on the accident severity rate and a separate model for the determination of the effect of education and fire criteria on the accident severity rate.

Model 2: ASR $_{i t}=\alpha_{0}+\alpha_{1}$ OHSC $_{i t}+\alpha_{2} P E R P_{i t}+u_{i t}$

Model 3: $A S R_{i t}=\gamma_{0}+\gamma_{1} T R N_{i t}+\gamma_{2} F R E_{i t}+v_{i t}$

Before panel data analysis, a unit-root test is performed to determine whether the data is stationary or nonstationary. If the series is stationary according to the unit-root test result, panel data analysis could be performed without any additional test (Barbieri, 2005: 6; Abdioğlu \& Uysal, 2013: 135-136; Y1ldırım, Mercan \& Kostakoğlu, 2013: 82).

The panel unit root test developed by Levin, Lin, \& Chu (2002) was used in this study to support the EViews 9 program. By the probability values in the test results, the series is estimated stationary. Thus, according to Engle \& Granger (1987), there will be no spurious regression in regression analyses, and findings will be reliable.

Coefficients in the model in this study were estimated using pooled panel data analysis, fixed-effects model and the random-effects model. As presumed in the pooled effects model, section and time factor in the model has no impact on the independent variable. In order to determine the most effective method of panel data analysis, the Hausman Test compares the fixed effects model with the randomeffects model. Impact of 3 out of 8 independent variables in total, according to the Fixed Effects Model and Random Effects Model, estimated to have a significance on ASR. Panel data analysis results based on these findings were carried out using EViews 9 program and by considering Random Effects Model, and findings were presented in Table 3.

Examining all three models in Table 3, by Random Effects Model, it is observed that two of the independent variables, OHS services and training, impact ASR, which is the dependent variable. In addition, independent variables, OHSC and TRN, were observed to hurt the dependent variable, ASR. However, other independent variables do not have a significant impact on ASR.

The former model's extent in explaining the dependent variable is indicated as; $\mathrm{R}^{2}$ coefficient of determination in Table 3 (Yalta, 2011: 73). For example, $\mathrm{R}^{2}=0,21$ value in Random Effects Model, / value indicated that the independent variables explain the dependent variable ASR by $21 \%$. In panel data analysis, $\mathrm{R}^{2}$ may be low if the time data of the research does not consist of an extended period. A low $\mathrm{R}^{2}$ value does not indicate any statistical issues (Gujarati, 2003: 260).

F statistic, in Table 3, shown with the aim of whether the independent variables in the models collectively have a significant effect on the dependent variable. Independent variables significantly affect dependent variables when the F statistic's probability value is less than 0,05 (Tari 2015: 81). Therefore, the probability value of F statistics estimated for the models concerning the Random Effects Model is less than 0,05; dependent variables in models are believed to have significance over ASR. 
Table 3: Panel Data Analysis

\begin{tabular}{|c|c|c|c|}
\hline \multirow[b]{2}{*}{ Model } & \multicolumn{3}{|c|}{ Random Effects Method } \\
\hline & (1) & (2) & (3) \\
\hline \multicolumn{4}{|c|}{$\begin{array}{l}\text { Independent } \\
\text { variable }\end{array}$} \\
\hline \multirow[t]{2}{*}{$F R E$} & -0.02 & - & $-0.05^{c}$ \\
\hline & $(0.49)$ & & $(0.08)$ \\
\hline \multirow[t]{2}{*}{ WRK } & 0.47 & - & - \\
\hline & $(0.94)$ & & \\
\hline \multirow[t]{2}{*}{$E L C$} & 62.82 & - & - \\
\hline & $(0.00)$ & & \\
\hline \multirow[t]{2}{*}{ HEA } & 0.0001 & - & - \\
\hline & $(0.79)$ & & \\
\hline \multirow[t]{2}{*}{ PERP } & -0.01 & -0.005 & - \\
\hline & $(0.11)$ & $(0.51)$ & \\
\hline \multirow[t]{2}{*}{ GNR } & -0.51 & - & - \\
\hline & $(0.17)$ & & \\
\hline \multirow[t]{2}{*}{ TRN } & $-0.01^{c}$ & - & 0.004 \\
\hline & $(0.07)$ & & $(0.38)$ \\
\hline \multirow[t]{2}{*}{ OHSC } & $-0.001^{b}$ & $-0.001^{a}$ & - \\
\hline & $(0.01)$ & $(0.00)$ & \\
\hline \multirow[t]{2}{*}{ Fixed } & $1.19 \mathrm{~b}$ & $1.35^{\mathrm{b}}$ & $0.81^{\mathrm{b}}$ \\
\hline & $(0.01)$ & $(0.01)$ & $(0.02)$ \\
\hline$R^{2}$ & 0.21 & 0.11 & 0.14 \\
\hline$\overline{\boldsymbol{R}}^{2}$ & 0.12 & 0.08 & 0.11 \\
\hline \multirow[t]{2}{*}{ F Statistic } & 2.28 & 4.48 & 1.70 \\
\hline & $(0.03)$ & $(0.01)$ & $(0.04)$ \\
\hline$D W$ & 2.23 & 2.13 & 2.12 \\
\hline
\end{tabular}

The final test in Table 3 is the Durbin - Watson (DW) autocorrelation test. DW test reveals the extent to which their antecedent values have impacted the data in the model. The model will not yield reliable results if the antecedent values impact data based on such a series. Autocorrelation test results showing approximately 2 indicates no autocorrelation (initial shocks being transmitted to posterior periods with the same extent) problem in the mentioned model (Tonta, 2008: 24). DW Test statistics obtained in the Random Effects Model were approximately 2. Therefore, it is estimated that predictions made in this study had no autocorrelation problem and obtained findings were reliable.

Subsequently, optimal costs were attempted to be estimated for the independent variables: occupational health and safety services, fire and training, which has a significant impact on the dependent variable ASR, according to the panel data analysis results for the 15 building construction projects included in the study.

The construction industry is dynamic; hence, occupational health and safety are not considered linear. For this reason, the relationship can be estimated as a parabolic equation. Optimal costs were attempted to be estimated by using the econometric model in the study as a result.

The following parabolic functions were created for each significant variable.

$$
\begin{aligned}
& A S R_{i t}=\beta_{0}+\beta_{1} O H S C_{i t}+\beta_{2}\left(O H S C_{i t}\right) *\left(O H S C_{i t}\right)+e_{i t} \\
& A S R_{i t}=\beta_{0}+\beta_{1} F R E_{i t}+\beta_{2}\left(F R E_{i t}\right) *\left(F R E_{i t}\right)+e_{i t} \\
& A S R_{i t}=\beta_{0}+\beta_{1} T R N_{i t}+\beta_{2}\left(T R N_{i t}\right) *\left(T R N_{i t}\right)+e_{i t}
\end{aligned}
$$




\section{In the equation:}

$A S R_{i t}$ : Accident Severity Rate

$\beta_{0}:$ Total Fixed Cost

$\beta_{1}$ : Unit Variable Cost

$e_{i t}:$ Refers to standard error.

The estimated results are / and/, and coefficients have statistical significance, reveals that the relationship between ASR and OHSC, FRE and TRN is a convex parabolic one. The expected graphic is shown in Figure 1.

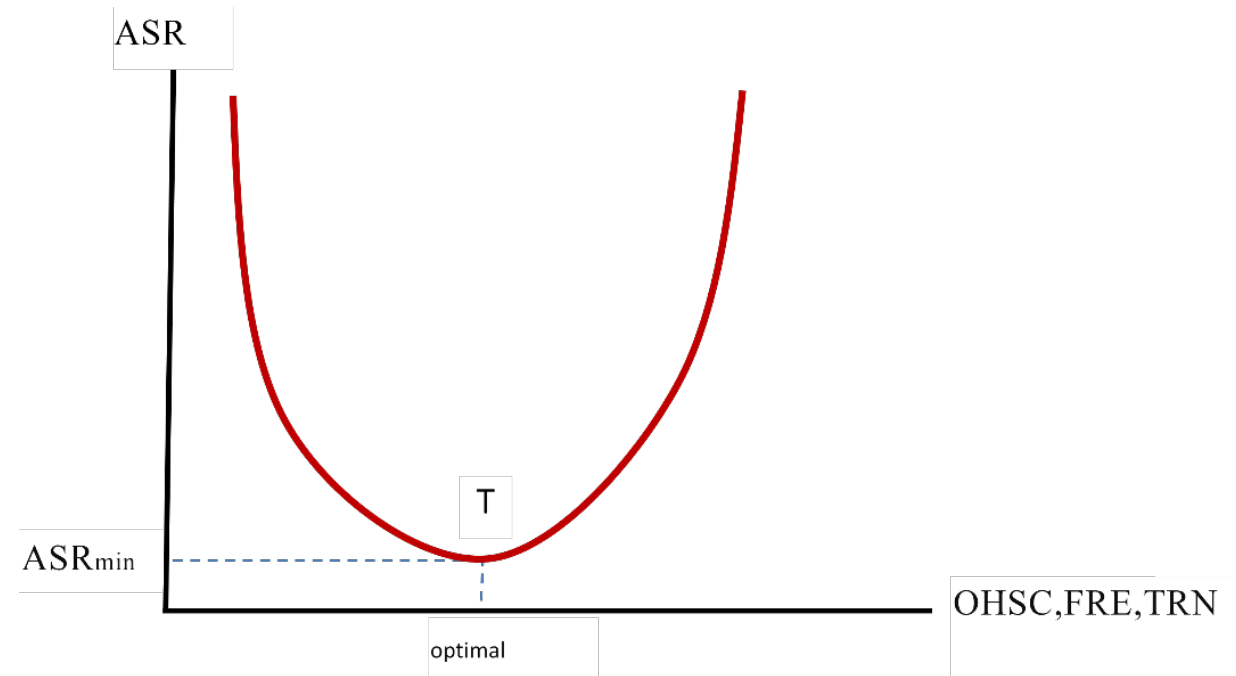

Figure 1: Expected Mathematical Relation between ASR and OHSC, FRE and TRN

In Figure 1, the T point is the turning point (in mathematics, vertex), at which the ASR will descend to the lowest level and OHSC, FRE and TRN will reach the optimal level. Even if costs for OHSC, FRE and TRN variables were increased after the T point, ASR would not change. The expected graphic, in that case, is shown in Figure 2.

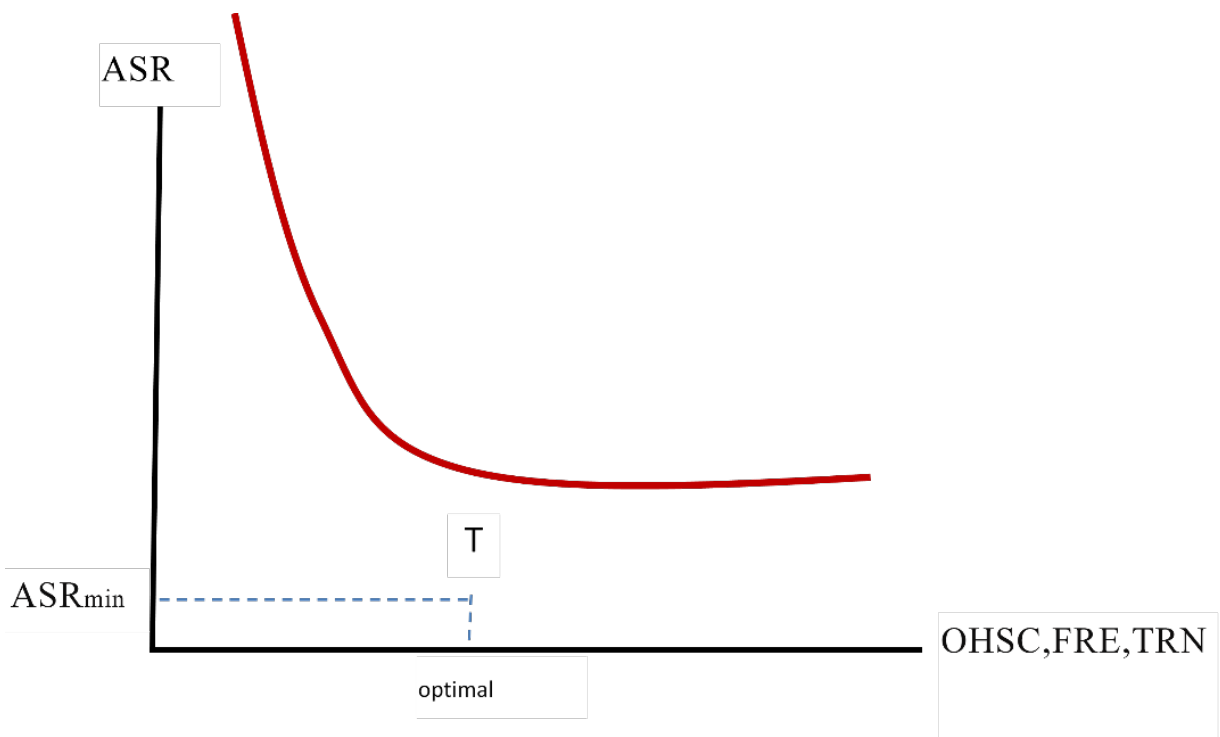

Figure 2: Expected Relation between ASR and OHSC, FRE and TRN

In Figure 2, the reason behind the horizontal continuing of the graph is that the increase in the OHSC, FRE and TRN costs does not require an increase in ASR. OHSC, FRE and TRN costs determined up to $\mathrm{T}$ point will decrease ASR, and additional costs from vertex do not decrease the ASR further. 
OHSC, FRE and TRN series, in this study, were multiplied by their values, and new variables such as (SOHSC: Square of OHSC), (SFRE: Square of FRE) and (STRN: Square of TRN) were generated.

Expected results from the equations are $\left(\beta_{1}<0\right)$ and $\left(\beta_{2}>0\right)$, by that, coefficients of independent variables to be negative and coefficients of their square to be optimistic and these coefficients to be statistically significant (Yamak \& Köseoğlu, 2009:397). The first-order derivative of ASR by OHS, FRE and TRN will be calculated to estimate optimal OHS, FRE and TRN costs using coefficients obtained from the equations. The value determining the first-order derivative to zero will show the axis of symmetry of the vertex, that is to say, the optimal OHS value (Yamak \& Köseoğlu, 2009: 387).

Optimal costs are shown in Table 4 below. Again, the model's significance was tested when the optimal costs were determined.

Table 4: Estimated Optimal Occupational Health and Safety Cost Results

\begin{tabular}{|c|c|c|c|}
\hline & ASR & ASR & ASR \\
\hline & $2.31^{\mathrm{a}}$ & $1.28^{\mathrm{a}}$ & $2.45^{\mathrm{a}}$ \\
\hline Fixea & $(0.00)$ & $(0.00)$ & $(0.00)$ \\
\hline OHSC & $\begin{array}{l}-0.005^{a} \\
(0.00)\end{array}$ & & \\
\hline $\mathrm{OHS}^{2}$ & $\begin{array}{l}0.00000292^{b} \\
(0.02)\end{array}$ & - & \\
\hline FRE & - & $\begin{array}{l}-0.1883^{b} \\
(0.02)\end{array}$ & \\
\hline$Y A N^{2}$ & - & $\begin{array}{l}0.005906^{c} \\
(0.10)\end{array}$ & - \\
\hline TRN & - & - & $\begin{array}{l}-0.0307^{b} \\
(0.01)\end{array}$ \\
\hline$E G T^{2}$ & 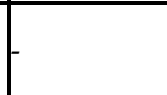 & - & $\begin{array}{l}0.000095^{b} \\
(0.02)\end{array}$ \\
\hline$R^{2}$ & 0.18 & 0.18 & 0.26 \\
\hline $\bar{R}^{2}$ & 0.16 & 0.11 & 0.18 \\
\hline F Statistic & $\begin{array}{l}8.14^{b} \\
(0.00)\end{array}$ & $\begin{array}{l}2.59^{b} \\
(0.02)\end{array}$ & $\begin{array}{l}2.168^{b} \\
(0.05)\end{array}$ \\
\hline$D W$ & 2.10 & 2.19 & 2.13 \\
\hline $\begin{array}{l}\text { Optimal } \\
\text { Costs }\end{array}$ & $856,1644 \mathrm{TL}$ & $15,941 \mathrm{TL}$ & $161,578 \mathrm{TL}$ \\
\hline
\end{tabular}

Footnote: $\mathrm{a}, \mathrm{b}$ and $\mathrm{c}$, indicates that the relevant coefficient is statistically significant, respectively, as $0.01,0.05$ and 0.10 . Probability values of $t$ and $F$ tests are shown in brackets.

\section{Conclusion and recommendations}

In the studies showing the contribution of OHS costs to occupational safety in the construction sector and its effect on preventing occupational accidents, it has been concluded that there is a negative relationship between occupational safety costs and accidents in general.

Brody, Letourneau \& Poirier (1990) developed an indirect cost theory to classify a comprehensive occupational safety cost to prevent occupational accidents. Zou, Shi \& Li (2010) conducted a study that the cost incurred for occupational safety will decrease occupational accidents. Another study on the impact of health and safety investments on construction company costs is by López et al. (2013) belongs. The results show that the average number of accidents varies in direct proportion to the total number of workers, an average number of subcontractors and occupational health and safety budget, and inversely proportional to the cost of accident prevention. 
A study of 79 contractors in the UK construction industry concluded that the overall benefits of accident prevention are approximately 3:1 more effective than the total costs of accident prevention (Ikpe, 2011).

Tang, Lee \& Wong (1997), for the optimization of occupational safety costs in construction, took the data on the investments made in occupational safety in building projects in Hong Kong and gathered these costs under three headings: occupational safety personnel, safety equipment and safety training. Here, they examined the relationship between occupational safety investment and safety performance.

According to a study conducted on 234 contractors responsible for building construction projects in Singapore, it was concluded that occupational safety investments have a strong positive effect on occupational safety performance (Feng \& Teo, 2009).

According to the panel data analysis results of the study, as the costs of occupational health and safety services, fire and training increased, accident severity rates has decreased. Thus, construction enterprises that want to decrease the accident severity rates in their projects need to emphasise occupational health and safety services, fire, and training criteria. The Random Effects Model was determined to employ the most effective method in panel data analysis; therefore, optimal cost analysis results were also evaluated utilizing the random-effects model. For 2017, optimal costs for the following variables were estimated as $856.16 \mathrm{TL} /$ per person for OHSC, (office-camp) 15,941 TL/m² for FRE and $161,578 \mathrm{TL} /$ per person for TRN. It is found that exceeding the estimated values, OHSC, FRE and TRN costs will reduce accident severity rates and be unnecessary for the enterprises.

In addition to the costs carried in obtaining occupational health and safety services, it is also believed essential for occupational safety specialists. Therefore, they will be employed to have experience in construction to detect dangers and risks easily.

In case of a fire situation, many fire extinguishers, fire detection and alarm systems should be possessed and checked periodically.

Besides the essential occupational health and safety training required by the law, training related to emergencies and first aid should be fully completed; keeping in mind that occupational health and safety culture starts from the high ranks, OHS awareness should be created, and external training should be held for the all personnel, including executives.

According to the panel data analysis results, other occupational health and safety criteria required by the law should be employed, although they have been estimated to have no significance in reducing the accident severity rates. In order to prevent on-site traffic accidents and vehicles rolling over, one of the reasons behind the work accidents occurring in construction sites, heavy construction equipment should be checked on periodically. Enclosing elevator shaft areas, external railing, and instalment of safety nets per the standards, collective protective measures considered general equipment costs, should be necessary for employers. Electric and grounding systems and lightning rods should be checked periodically, at least once a year, following the "The Regulation of Health and Safety Requirements for the Use of Work Equipment". Pre-recruitment and post-recruitment health examinations should be held by considering the risks of the work environment. Health examinations should be held at least once a year in the construction industry and pre-recruitment for each employee. Personal protective equipment should be determined pre-recruitment by taking risks and dangers employees will be exposed into consideration, and whether if the employees use this equipment should be audited.

\section{Peer-review:}

Externally peer-reviewed

\section{Conflict of interests:}

The authors have no conflict of interest to declare.

\section{Grant Support:}

The authors declared that this study has received no financial support. 


\section{Author Contributions:}

Idea/Concept/Design: Z.F.O.., G.Ü. Data Collection and/or Processing: Z.F.O. Analysis and/or Interpretation: Z.F.O., G.Ü., G.D.D. Literature Review: Z.F.O. Writing the Article: Z.F.O. Critical Review: G.Ü., G.D.D. Approval: G.Ü., G.D.D.

\section{References}

Abdioğlu, Z. \& Uysal, T. (2013). Türkiye'de Bölgeler Arası Yakınsama: Panel Birim Kök Analizi. Ataturk University Journal of the Faculty of Economics and Administrative Sciences 27(3,2), pp. 125-143.

Barbieri, L. (2005). Panel Unit Root Tests: A Review. Quadernı Del Dipartımento Di Scienze Economiche E Socialı.:43 (1-55).

Bird, F. (1974) Management Guide to Loss Control. Institute Press, Loganville, Georgia, ABD.

Briesemeister J. K. (2018). Managing Complex Construction Projects, (2018): A Systems Approach, Auerbach Publications, Broken Sound Parkway NW.

Brody, B., Letourneau, Y. \& Poirier, A. (1990). An indirect cost theory of work accident prevention. Journal of Occupational Accidents, 13, 255-270.

Bütüner, O. \& Uzun, D. (2010). 'İş Kazalarının Maliyetleri ve Hesaplamaları Üzerine Bir Araştırma' MYO-OS 2010- National Vocational Schools Student Symposium, Düzce.

Ceylan, H. (2012). "Türkiye'deki İş Sağlığı ve Güvenliği Eğitimi Sorunlar ve Çözüm Önerileri”, Electronic Journal of Vocational Colleges. Volume: 2(2), 2012, pp. 94-104.

Cohen, A. (1977). Factors in successful occupational safety programs. Journal of Safety Research, 9, 168 $-178$

Engle, R. F. \& Granger. C. W. J. (1987). Co-Integration and Error Correction: Representation, Estimation and Testing. Econometrica 55: 251-76

Everett J. G. \& Frank Jr., P. B. (1996). Costs of accidents and injuries to the construction industry, Journal of Construction Engineering and Management, Vol. 122, Issue 2, June 1996).

Feng, Y. \& Teo, A. L. (2009). Safety investment and safety performance of building projects in Singapore. Proceedings of CIB W099 International Conference Working Together: Planning, Designing and Building a Healthy and Safe Construction Industry, 21-23 October 2009, Melbourne, Australia.

Gerek, N. (1998). Türkiye'de İşçi Sağlığı ve İş Güvenliği, Türk-Metal Sendikası Yayını, sy.12, Ankara

Gujarati, D. N. (2003). Basic Econometrics, Fourth Edition McGraw Hill.

Gujarati, D. N. (2004) Basic Econometrics. 4th Edition, McGraw-Hill Companies.

Gürcanlı, G. E., Bilir, M, S. \& Sevim, M. (2015). Activity-Based Risk Assessment and Safety Cost Estimation For Residential Building Construction Projects. Safety Science, vol.80, 1-12.

Heinrich, H. W. (1931). Industrial Accident Prevention: A Scientific Approach. McGraw-Hill, New York.

Ikpe, E. (2011), Improving Construction Health and Safety: Application of Cost-Benefit Analysis (CBA) for Accident Prevention, The International Journal of Construction Management, Vol. 11 No. 1, 1935.

Keskin, Y. (2016) <https:/ / www.İSGnedir.com/is-kazasi-siklik-agirlik-orani-nasil-hesaplanir

İş Kazası Sıklık ve Ağırlık Oranı Nasıl Hesaplanır? (Date of access: 12.07.2019).

Khan, S. (2011). www.khanacademy.org. <https://tr.khanacademy.org/economics-financedomain/macroeconomics/gdp-topic/real-nominal-gdp-tutorial/v/example-calculating-real-gdpwith-a-deflator, (Date of access: 15.04.2019).

Koç, M. \& Akbıyık, N . (2011). Türkiye'de İş Kazalarının Maliyetleri ve Çözüm Önerileri . Akademik Yaklaşımlar Dergisi , 2 (2) , 129-175 . Retrieved from

Kök, R. \& Şimşek, N. (2005). Panel Veri Analizi Panel Veri Analizi. http:/ / debis.deu.edu.tr/userweb//recep.kok/dosyalar/panel2.pdf, (Date of access: 08.04.2019). 
Loosemore, M. \& Andonakis, N. (2007). Barriers to implementing OHS reforms - the experiences of small subcontractors in the Australian construction industry. International Journal of Project Management 25 (6), 579-588.

López, A., M., Ibarrondo-Dávila, M. P., Rubio-Gámez, M. C., \& Munoz, T. G. (2013). “The impact of health and safety investment on construction company costs". Safety science, 60, 151-159,

Miller, T. R. (1997). Estimating the Costs of Injury to U.S. Employers. J Saf Res., 28(1):1-13.

Montero, M.J., Araque, R.A. \& Rey, J.M. (2009). Occupational health and safety in the framework of corporate social responsibility. Safety Science. 47 (10), 1440- 1445.

SGK, (2018). SGK, Social Security Institution Statistics Yearbook http://www.sgk.gov.tr/wps/portal/tr/kurumsal/istatistikler/sgk_istatistik_yilliklari

Smith, R. S. (1979). The impact of OSHA inspections on manufacturing injury rates. Journal of Human Resources, 14, 145 - 170

Tang, S.L., Lee, H.K. \& Wong, K. (1997). Safety cost optimization of building projects in Hong Kong. Construction Management and Economics, 15, 177-186.

Tari, R. (2015). Ekonometri. (10. Bask1). Umuttepe Publications, Kocaeli.

Tonta, Y. (2008). “Regresyon Analizi Ders Notları”, Hacettepe University. Ankara.

Torres-Reyna, O. (2007). Panel Data Analysis Fixed and Random Effects using Stata (v. 4.2).

Sousa. V., Almeida N. M. \& Dias, L. A. (2014)."Risk-based management of occupational safety and health in the construction industry - Part 1: Background knowledge", Safety Science, Say1: 66, 2014, pp 75-86.

Yalta, A. T. (2011). Ekonometri 1, Ders Notlar1. TOBB University of Economics and Technology, October 2011. Ankara.

Yamak, R. \& Koseoglu, M. (2009). Uygulamalı İstatistik ve Ekonometri. Trabzon.

Yıldırım, K., Mercan, M. \& Kostakoglu, F. (2013). Satın Alma Gücü Paritesinin Geçerliliğinin Test Edilmesi: Zaman Serisi ve Panel Veri Analizi. Eskisehir Osmangazi University Journal of the FEAS, 8(3), pp. 75- 95.

Zou, P. X. V., Shi, V. Y. \& Li, Z. (2010). “An econometric evaluation framework for investment in construction safety", 26th Annual ARCOM Conference; 2010 Sep 6-8; 